\title{
The Trading Profiles of Community Retail Enterprises
}

\author{
Eric Calderwood and Keri Davies
}

Institute for Retail Studies, Stirling Management School, University of Stirling, Stirling, UK

\begin{abstract}
Purpose - The purpose of this paper is to investigate the key features of the Community Retail Enterprises sector in the UK
\end{abstract}

Design/ methodology - This paper reports on the results of a postal questionnaire survey of 197 Community Retail Enterprises. The information gathered from this survey was supplemented by visits to 21 of the shops run by these Enterprises and short interviews with some of the shop staff.

Findings - The Community Retail Enterprise sector is growing very quickly with a significant number of new shops opening every year in the UK. It is a very diverse sector which provides a wide range of goods and services reflecting the desire to meet the needs of members and local residents. It is heavily dependent on the involvement of the local community, particularly as volunteers, but this can lead to other tensions around the role of the shop and the enterprise in general.

Originality/ value - This paper provides an overview of an area of retailing which is growing in size and will be of interest to those involved in policy-making in rural areas.

Keywords - Retailing; Small shops; Community; Co-operation; United Kingdom

Paper Type - Research paper 


\section{Introduction}

If modern societies are to try to switch towards supporting more sustainable lifestyles, whether in terms of individual product choices or in terms of overall levels of consumption of the earth's resources, then distribution systems that support this change are going to become even more important. Along with a range of other well-documented economic, social and political trends, the trend towards large retail stores has led to the identification of so-called 'food deserts' in both urban (Wrigley 2002) and rural locations (Bitto et al, 2003). But, in addition, once a local population comes to rely on car travel for either shopping or work, it tends to increase their usage of and dependency on more distant locations and thus it also increases the likelihood that other services will be lost to local communities (Fulton and Hammond-Ketilson 1992; Gray et al, 2001; Findlay and Sparks, 2008).

It is for this reason that the public has become more interested in the plight of the small or independent shop in recent years (Clarke and Banga, 2010). What was once seen as primarily a problem for remote, rural communities is now seen to be affecting prosperous and otherwise successful villages close to urban areas and even local neighbourhoods within larger urban areas. The use of the presence of small shops as an indicator of the health of a community and the advantages of retaining such shops are now part of public policy in, amongst others, Scandinavia (Eckhaugen et al, 1980), the United Kingdom (Kirby 1981; Calderwood and Davies 2006; Paddison and Calderwood, 2007; Bennison et al, 2010), Ireland (Briscoe et al, 2000; Carrigan and Buckley, 2008), Japan (Kurimoto 2005), Canada (Fulton and Hammond-Ketilson 1992; Winnington-Ingram 2003) and the United States (Cotterill 1982).

However, the pressures on private or investor-owned small shops are so great that even with public sector support many still struggle to survive. A number of commentators have argued that community-run or small co-operative shops might be one possible response to these problems because of their grounding in local communities (Fairbairn 1989; Fulton and Hammond-Ketilson 1992; Fairbairn 2005; Birchall, 2011). As such, they could fit within the Big Society project (Norman, 2010) which has been adopted by the UK government since 2010 and which aims to enhance social capital by allowing communities to take more responsibility for local activities. The issues around food quality and safety, which have been championed by many of the food co-operatives in the United States, would also suggest that 
this form of retailing is well matched to promoting sustainability (Danforth 1981; Singerman 1982; Cox 1994; Williams, 2007; Blay-Palmer and Donald, 2007).

But if community-run shops are to be a possible solution to the problem of local food provision and overcoming social isolation, particularly in rural areas, then there is a need to understand better the dynamics behind the formation and survival of these shops. This paper is based on a survey of community-run shops undertaken in 2009. In looking at these community-run shops, there is a wide range of terms used in this area, including community retail enterprise, community-owned shops, village shops, community co-op and so on. For the remainder of this paper we will use the terms 'community retail enterprise' (CRE) to refer to the legal entity that established or runs the shop and, where it is necessary to distinguish them separately, 'community shop' for the shops

\section{What is a 'community shop'?}

There is no single definition of a community shop or community retail enterprise. DEFRA (2006) looked solely at the community-owned village shop sector in England, which it characterised as being comprised mainly of convenience stores, although some also stocked local and specialty foods. DEFRA suggested that the conditions that are particularly suitable for CRE development are: settlement size (normally between 200 and 900 people); the absence of another shop within walking distance; and, specific demographic characteristics, particularly high levels of people who are well-educated, professional aged between 45-64, commuters and high-earners (DEFRA, 2006, pp.65-66). They suggested that there were around 3,000 rural communities in England which could support a CRE, and over 1,000 which were particularly conducive to such enterprises.

However, there is no particular reason for CRE to be restricted to villages or rural areas. The Plunkett Foundation (www.plunkett.co.uk) suggest that the main defining character is that there is community involvement in either the setting up or running of the shop, with a management committee responsible for ensuring that the shop is financially viable (Perry and Alcock, 2010). All CRE are businesses and as such they must have a recognised legal structure in order to trade. The majority have become limited associations registered under the Industrial and Provident Societies Act; other options include companies limited by guarantee and community interest companies. There usually needs to be some form of annual reporting to the membership, either through a formal AGM, a social event with presentation or a printed report. 
There is a qualification that needs to be added to these statements. The scope of the DEFRA study may have meant that it could not include some forms of community shop. For example, multi-function or multi-service shops were popular in Scotland in the 1980s (Calderwood and Davies, 2006) and were promoted as a possible solution for rural England twenty years later (Moseley et al, 2004; Bovaird, 2007). Similarly, some of the larger community shops in the North-West of England which are run as local co-operative societies were not included in the DEFRA study.

The variety of different types and independent spirit of CRE trading throughout Great Britain does not facilitate the production of a definitive list of this type of business. This generally reflects the unregistered and varied nature of the sector with no controlling body and with enterprises responsible only to themselves and their supporters, both corporate and individual. The most comprehensive record of CRE has been developed by the Plunkett Foundation and this provided the foundation of the database that has been used in this analysis. However, additional enterprises were added to the list where they could be identified, particularly in Scotland based on information from the Scottish-based Community Retailing Network, whilst some business closures were also noted. This work identified a total of 197 CRE in mid 2009 - 179 in England, 12 in Scotland and 6 in Wales.

\subsection{The Scope of the Study}

Given the varied nature of the sector, a two-pronged approach was used for the survey work. First, a written questionnaire was developed (based, in part, on that used in a previous survey of Scottish community co-operatives (Calderwood and Davies, 2006)). This was mailed to all 197 of the identified enterprises, along with a covering letter explaining the context of the survey work.

In total, there were some 103 responses to the questionnaire, of which 94 could be used in this Study. Some questionnaires were returned unopened and marked 'not known' whilst others stated that the enterprise had closed. Given the timescales involved in the survey work it was not possible to mail out a second wave of questionnaires to those enterprises that had not responded. Nonetheless, the resulting $48 \%$ response rate is considered to be a robust sample. Roughly two-thirds of the questionnaires were completed by a member of the CRE's management committee and one-third by the shop manager. These different roles and different levels of knowledge of aspects of the CRE's work may have introduced some bias 
or inaccuracy to the results which could not be avoided given the nature of the CRE themselves.

In Phase 2 of the research, some 21 community shops located in England (Cumbria and the Lake District; Oxfordshire; Worcestershire and Staffordshire), Scotland (Western Isles and Stirlingshire) and Wales were visited to provide additional insight and depth of answer. The shops were chosen to cover the full range of different CRE formats that had been identified from the questionnaire survey. However, largely because of the difficulties of arranging a schedule over such a wide geographical area, most of these visits were made unannounced. Nonetheless, it was still possible as part of each visit to speak to some of the wide variety of community activists participating in their operation. These individuals ranged from paid and volunteer shop staff and shop managers through to CRE committee members and directors. The relatively unstructured approach to these interviews reflected the exploratory nature of this stage of the research.

\section{The Study Findings}

\subsection{The Pattern of CRE Development}

Analysis of the responses to the questionnaire highlights a series of development phases within the sector (Table 1). The percentage of respondents from each of the three countries was close to half of the original populations: 84 from 178 in England; 7 from 13 in Scotland and 3 from 6 in Wales. Whilst the earliest shops represented in the Study are traditional cooperative societies formed in the late nineteenth century, these were included as they represent single outlet CREs which remain focused upon a very local population.

\section{Insert Table 1 about here}

The modern phase of the development of community shops probably began in the 1970s in the Highlands and Islands of Scotland. Enthused by the Gaeltacht model of community businesses operating in Ireland (Briscoe et al, 2000) and encouraged by the publicly-funded Highlands and Island Enterprise, a number of multi-functional businesses were established in many outlying areas of Scotland from 1980 onwards (Gordon, 2001). These businesses were more than just shops being initially encouraged to set up a variety of activities including fish farming and craft manufacturing; however, in the intervening years they have become increasingly focused on customer facing businesses. 
The latest development phase began during the 1990s with an initially relatively slow rate of growth gradually building from around 1998 towards the much more rapid expansion of interest in the sector which is taking place in recent years. In England this growth has resulted in a number of 'clusters' of CREs, particularly in the South-West (23 shops in the sample) and the South-East (29 shops). The existence of these clusters is believed to be the result of not only the local competitive and demographic environment but also the intervention of key agencies such as regional development bodies, rural community councils and the Plunkett Foundation-based Rural Community Shops (formerly known as ViRSA) (f3, 2004; Shepherd, 2005; DEFRA, 2006).

Respondents overwhelmingly described the location of their CRE as rural (97\%). The use of the term 'rural' in the questionnaire was not defined precisely to allow respondents to express their views. This has resulted in CREs located in the green belt between Wolverhampton and Cannock being broadly categorised alongside one in the Lake District or another on one of the more outlying of the Orkney Islands. Only 3 of the respondents identified their CRE as urban, ranging from a small community shop focusing on the delivery of post office services needs for local residents in Iffley, a middle-class suburb of Oxford, to the environmentally aware Unicorn Grocery, a worker co-operative selling 'local organic, fairly traded and wholesome' foods in South Manchester. Again, these begin to provide an explicit illustration of the diversity of the sector.

\subsection{Reasons for the Development of a CRE}

The principal reason for the establishment of a CRE is quite unambiguous - it is the preservation of the local shop or post office within the community (Table 2). Given by over 95\% of the respondents to the questionnaire it was also stressed regularly in interviews in the community shops by a wide assortment of activists including directors, managers and staff. Without the community shop, most of the communities would have had no retail outlet; 77 (82\%) of the respondents said that there were no other local shops of any type. In addition, some 65 (69\%) respondents said that there were no other retail outlets locally i.e. no bank, Post Office or pharmacy. The lack of a shop contrasted with the current provision of other community facilities, with almost all of communities reporting the presence of a church (92), a village hall (90), hotel or public house (84), primary school (75) or daily bus service (71). 
Many CREs were formed following the acquisition of the business from the previous owners to ensure continuity of service. Some resulted from indications of the previous owners that they would be willing to sell to the community whereas others followed more direct action by local activists to create a CRE once it became clear that the shop was about to close.

In terms of how the members of the CRE would judge whether or not the business was a success, many of the same factors reappeared, in particular, the retention of the shop in the community and the associated need for financial viability. One additional and very important factor was a desire to retain community ownership and control once the CRE had been established. It was clear that one of the roles of the management committee was to link the shop to the community, providing not just an independent minded set of views around the running of the shop but also bringing skills that could be provided free of charge to the CRE. These ranged from undertaking painting, plumbing or electrical work on a store to accounting skills, public relations or fund-raising.

One way the change of ownership could make a difference was that the new enterprise was then able to gain advice or even financial aid from external bodies. The level of support and guidance provided by external agencies such as the Rural Community Councils and Community Shops Network (formerly ViRSA) in England and Wales or the Community Retailing Network in Scotland were often influential in this process. During the previous year 39 (41\%) CREs had received funding and 53 (60\%) had received some form of training assistance, consultancy or other advice from an external body or agency. Support was most evident in the newer fledgling enterprises with a variety of bodies providing grants to get the business up and running. A third of the successful grants were used to acquire an existing business, to refurbish premises or other initial costs. Awards for this type of investment came from a wide variety of sources including the Big Lottery Fund, the Co-op Foundation, ViRSA grants, County and District Councils, regional development agencies and their designated delivery partners, Rural Community Councils, Community First NEXUS grants, Communities Scotland, Highland and Islands Enterprise and even Tesco.

Smaller grant schemes have supported the purchase of a range of equipment by CRE, most commonly the purchase of new refrigeration equipment but help has also been given to buy labelling machines, pricing guns, scales, A-frames and an EPOS system. Support was also received for a variety of short and medium term projects, ranging from help for local post offices and the funding of a shop manager to the provision of advice on retail marketing. 
Apart from finance, CREs also benefitted from support in two key areas. The first was the creation of support groups for the sharing of 'best practice' and the resolution of common problems. In Scotland this has been operating since 2001 under the auspices of the Community Retailing Network; in England it has been organised initially by some of the Rural Community Councils, particularly those in Oxfordshire and Norfolk, and latterly by the Plunkett Community Shop Network.

The second factor is the support provided to CREs by other retailers. The established consumer co-operatives (including the Co-operative Group, Midcounties Co-op and Penrith Co-op) were most evident but Sainsbury and Tesco have also been involved. For example, Co-operative and Community Finance provided help and advice on finance, whilst the Cooperative Group helped with operational procedures and training, advice on ethical issues, and even the provision of free second-hand shelving and fridges. A number of the Scottish community co-operatives have been able to work with the manager of a 'buddy' store of the Co-operative Group who can provide advice within a longer-term relationship. Finally, the largest of the community retail enterprises have also benefitted from direct deliveries from the Co-operative Retail Trading Group, which is the central buying group for co-operative retail societies in the United Kingdom.

In contrast, Tesco focused their support on the provision of advice on store layouts and operational procedures; the provision of equipment (shelving and refrigerated cabinets), and advice on how to organise the shop. Whilst there was uncertainty in some of the CRE regarding the reasons that had encouraged Tesco to become involved, a noticeable number of communities had benefitted from their assistance, offered primarily through Tesco's One Stop subsidiary. This scheme seems to have been less active recently however.

\subsection{The Trading Activities of the CRE}

Community shops come in all shapes and sizes but many are very small and a very high proportion of stores traded from a sales area below $500 \mathrm{sq}$. ft. Few of these shops would be considered suitable for a convenience store development by a larger multiple retailer. Whilst making them easier to manage operationally, the constraints of shop size has implications for the depth and width of range that can be stocked.

The scale of the community shop operations is emphasised when the shop size is crosstabulated with the average weekly turnover (Table 3). It can be seen that 30 (45\%) of the shops lie in the shaded area which covers the two smallest sales area bands and two lowest 
turnover bands. These are very small, local operations and it helps to explain why a number of the previous owners of these businesses might have found it difficult to sell privately. The combination of low turnover and high fixed and personnel costs required to operate a shop with the trading hours expected of a convenience type store would make it difficult to adequately staff the shop with paid employees.

\section{Insert Table 3 about here}

Significantly, however, many of the CRE reported that their results were improving. Almost $60 \%$ of established shops stated that they had increased turnover compared with the previous year whilst a further $28 \%$ stated that it had remained the same. Perhaps more crucially, over $71 \%$ of respondents reported that they had made a surplus in the last financial year. Although this means that more than one in four did not, ten of the shops had not been open long enough to be able to make a meaningful comparison. Any profits were most likely to be reinvested in the business (79\%), whilst 6\% of CRE would use them to repay outstanding loans; $10 \%$ would pay a dividend to members and the remaining $5 \%$ would donate any surplus to local causes.

It has already been noted that most of the shops do not have any local competitor but this does not mean that the shops are not being affected by other retailers. Almost three-quarters of the communities sampled have a home delivery service operated by one or more of the major supermarkets; Tesco, Sainsbury and Asda were mentioned specifically. Whilst recognising that some people will always obtain their shopping needs with deliveries by one of the multiples, these services were seen to cause a continuous outflow of spending from the local communities.

\subsection{The Retail Offer}

As might be expected, the CRE exhibited a range of usage patterns. Whilst some community shops were 'busy' throughout the trading day others had quite distinct highs and lows. Some experienced the impact of more mobile residents who commuted out of the village to work only returning in the evening whilst others benefitted from being used all day. Some are used primarily for convenience or distress shopping whilst others were used as the local larder and occasionally as a quality delicatessen.

Because there is no overall formula for the sector, the CREs attempt to meet the needs and wants of their local communities. The shops are often quite distinctive in their product offer 
and try to differentiate themselves from local supermarkets. Stores such as Chadlington and Feckenham seek to provide up-market products which are very distinctive and which might even draw customers from across a wide area. Others such as Leafield or Ascott-underWychwood try to draw in passing trade through the provision of home-made sandwiches or hot food. Blockley, Langdale and Coniston provide a wide range of products that appeal to tourists and walkers.

Respondents regularly emphasised the trading benefits associated with flexibility of the retail offer in response to perceived or more tangible local demands, particularly a desire to provide improved access to fresh foods and to locally sourced goods. Over $90 \%$ of respondents stated that their customers look for and support local products. The goods most commonly bought from local suppliers were bakery goods (85\%), chilled foods e.g. cheeses, fish and butchery (84\%), fresh fruit \& vegetables (78\%) and crafts (51\%). This strong level of support was also evident in those shops which were visited during the investigative phase of the Study. For example, the Unicorn worker's co-operative in Chorlton, Manchester is developing its own farm and it also displays a narrative explaining some of their sourcing choices.

The area is not always clear cut however. Whilst some highlighted local product features such as "flour milled down the road," another respondent stated that customers looked for local products only "if the price is right," whilst another stated that not all customers were interested. In addition, many of the CRE took delivery of chilled foods from local farm shops which appear to have been looking for additional retail outlets primarily, but not solely for their own products. However, occasionally, this service created some competition issues with the farm shops who also delivered direct to other customers around the CRE.

Another quite distinctive aspect of the community shops is the presence of very locally produced products ranging from local residents making cake for a café or marmalade for the shop to others who bring in surplus fruit and vegetables from their gardens. However, this can lead a glut at some times in the year and some managers were reluctant to accept the additional risks posed by this sort of product for food safety issues.

The stocking of organic or ethical goods was not so important overall but the results may point to two groups of shops here. Those whose customers saw ethical goods as just one possible element of the range and those where the customers saw these goods as essential and as a consequence the shops were much more enthusiastic supporters of stocking a "range of fair trade goods" and "more awareness of organic, Fair Trade, Co-ops, ethical shopping." 
Around $40 \%$ of the sample reported that the supply of organic and ethical products was important to them but whilst the demand for organic products was fairly widespread there was a bias towards Central England (particularly Gloucestershire and Oxfordshire) for those CRE focused on providing ethical products.

The overall comparison of the products stocked in community shops not only identifies a quite wide variety of different retail offers but also serves to emphasise the degree of difference that exists (Table 4). Whilst a significant proportion of shops stock a range of ambient groceries and chilled and frozen foods, there is still a conspicuous number which do not. Whilst it might not be so unexpected that more than a third of shops are not licensed to sell wines and spirits, it is perhaps a little more surprising that around $10 \%$ of shops do not sell any bakery goods.

\section{Insert Table 4 about here}

The differences in community shop offer are even more evident in the comparison of non food products being sold (Table 5) and the services being offered (Table 6). This does help to begin to differentiate between different shop formats and how they are satisfying their particular customer needs. For example, in Table 5, the three shops selling petrol and diesel are all located in Scotland (Eday, Ollaberry and Uig).

\section{Insert Table 5 about here}

But some of the biggest differences between CRE (and between CRE and other local shops) come in terms of the range of services that they offer through the shop. For example, responding to the limited number of pharmacies in local communities some shops pick up prescriptions for customers whilst others have a similar service for dry cleaning and even allow parcels to be dropped-off. The local relationship is carried forward with the sale of tickets to local events and the provision of community information, as well as tourist information. Additional activities include a vegetable box delivery scheme (Twyford), whilst a number of CRE in tourist areas, such as Welcombe, Coniston and Uig all make up and provide holiday boxes of groceries for visitors (Table 6).

\section{Insert Table 6 about here}

Nevertheless, the responses to the questionnaires and the interviews of management and staff identified some tensions in the CREs. One aspect of this is the impact of an ageing 
population in rural communities. This was a common theme emerging from the interviews with quite disparate views showing some potential to create tension in some shops as they are pulled in different directions. Whilst some interviewees referred to their shop as being "not just for older people", others spoke of "lots of people living in the area are youngish retired" as well as taking the view that the shop was "providing a service for the elderly and vulnerable”.

The diverse socio-demographic profile of rural communities was a further recurring theme in our interviews. One interviewee spoke of local residents who could not afford more expensive local products and therefore felt that the shop was failing to achieve a necessary balance. This need to satisfy a broader section of local customers was recognised by many enterprises. As one interviewee explained that despite the relative affluence of the area it was "terribly important to balance the stocking of duck breasts with the provision of standard bread. This is about a community, not about supplying rich people.” As well as local residents, a number of other customer types were identified ranging from local builders and other often transient workers in the community, local holidaymakers and walkers and more general 'passers-by'.

\subsection{Retail Pricing}

The responses to the questionnaire might suggest that community shops accept that they cannot compete with larger stores on price. They attempt to get around this by stressing the overall cost of the shopping trip and by providing products that may not be stocked in a supermarket. Whilst many of the shops in England were within five to ten miles of a large store, in Scotland a visit to the nearest competitor might require a seventy mile round trip including a ferry journey. The impact on the performance of the community shops was illustrated clearly by a comment from the Polstead shop; "as petrol prices rise, customers find our prices compare favourably with supermarkets.”

However, the shop visits did show that several shops were less willing to take this view. More general sensitivity to pricing was evident with Rattlesden's attempt to “keep profit margins low and prices competitive", while Radley was looking to have the "ability to sell local produce at reasonable cost." Some shop managers stressed that they checked the prices of key lines against those in the local supermarket and aimed to match or even beat them on price. 


\subsection{People}

Local people are often identified as being crucial to the success of a CRE as they comprise not only a crucial customer base but also provide many of the employees in the shop. This dependence goes further in the smaller shops where local volunteer staff provide the only basis on which some enterprises can survive.

The relationship of these two, often intertwined groups with the local enterprise can be seen to develop into a long-term commitment and ongoing engagement and can result in an attitude coming from a sense of benefit and ownership illustrated by comments such as: "the village owns the business". This relationship begins to explain why it is so important to ensure that local people continue to relate to the CRE and help to make the enterprise work by volunteering. This view was expressed in many ways such as the following comments from the managers of two enterprises illustrate: "This place wouldn't run without the people." and "Volunteers, without them the shop would not exist."

Volunteers don't just contribute towards the well-being of their local community; they also described how working in the shop provided a point of contact with other residents and often reduced the sense of isolation that they had felt previously. Thus, the shop can fulfil a variety of roles, making it a social hub which facilitates informal meetings and provides a focal point for many residents. Apart from the type of comments such as "(there is a) lot of chatting in the store”, the shops were also seen to provide other key institutions in the community such as the church with an opportunity to engage not only with regular church-goers but also with the wider community e.g. vicars were serving in two of the enterprises during our visits.

In addition, community shops can create local employment a critical factor especially in more remote locations and thus contribute to helping people stay in the area. For example, the Uig Community Shop on the Isle of Lewis now employs over six FTE staff and has become the largest employer in the local area following the closure of the local fish farm.

The variety amongst the CRE becomes quite evident following a comparison of their staff and management profiles. Around three-quarters of CRE have either paid full-time or parttime members of staff (Table 7) but these are generally either the shop manager or the Post Office manager. The majority of community shops remain very dependent upon unpaid volunteers who contribute their time to the community. For example, the Appleton manager stated that, "The village supports the village shop, many people work there." 


\section{Insert Table 7 about here}

There was a clear link here with scale as many of the stores with the lowest levels of turnover were staffed solely by volunteers. Clearly there will be a link here between the profitability of the store and the ability to pay managers or other staff. But it is also the case that as the volume of trade increases so does the need for professionalism and consistency and this can lead to a level of frustration at a lack of skills or the time required to run the store effectively. The inter-relationship between the success of the community shop and the availability of volunteer members of staff is illustrated by the comment of the Ibstock shop manager, that a “shortage of volunteers restricts opening hours.” However, volunteers have sometimes blocked changes, either because of their limited retail experience of because of their reluctance to embrace change.

As a possible indicator of success, stores which had been open longer were more likely to have full-time staff - although it might also show a degree of weariness and volunteering fatigue amongst volunteers. It does however raise some potential concerns over management and governance issues that might arise as the shops move from being something new in the community to a fixture, with less direct community involvement in its day-to-day activities.

\section{Conclusion}

The growing number of CREs shows the level of resources that local communities can mobilise when residents feel threatened or are convinced that their efforts can truly make a difference. The provision of pump-priming funds and timely information from bodies such as the Plunkett Foundation has resulted in local retail provision being saved in a relatively large number of locations in recent years.

However, most CREs offer much more than just the retention of a shop, important as that can be for many local residents. Their presence may also help to retain people in rural areas or attract new residents as they can provide a 'heart' for the community that helps to renew social networks. They can also be seen to support or stimulate local economic initiatives with some of the CREs regenerating local employment opportunities, both directly through full and part-time employment and also indirectly through support for other local businesses and producers. Local public bodies may use a community shop as a hub for the co-delivery of services in their local communities. In these ways they may also help to reduce the distances that people or products have to travel to fulfil their basic needs. 
Nevertheless, the stories from many of the CREs also show the limits of a project such as the Big Society. Once the initial enthusiasm and flush of success begins to fade it can be difficult for a CRE to retain members and to compete successfully against larger retailers, especially where those competitors run delivery services into rural areas. Without a wider support network they can struggle to source products efficiently and effectively leading to high prices or limited availability. Initially, these deficiencies are balanced out in consumers' minds by enthusiasm and the convenience of local provision. But, if those same consumers start to forget the origins of a CRE and start to treat it as 'just another shop' then the CRE can enter into the same downward spiral that led to the need for it in the first place.

Therefore, we need a greater recognition that it is not enough just to support a CRE to the point where the community shop opens for business. On the one hand, the activities of the Plunkett Foundation can nurture local social capital by supporting each CRE and by bringing them together to exchange best practice; on the other hand, the community shops also need to be viable trading entities. For some, the need is for better access to competitively priced sources of supply rather than being forced to keep prices down through an over-reliance on volunteers and the goodwill of local consumers. Alternatively, others may want to develop genuine collaborative relationships with local suppliers or producers in order to create a more distinctive position from which they can maintain their business.

Critically, established CREs must recognise that the needs and expectations of local supporters, both volunteer workers and active trading supporters, may change with the trading environment or as the CRE matures. These changes have to be evaluated on a continuous basis and then considered by the CRE to ensure that, through the community shop, they continue to address what is important to their local community.

\section{References}

Bennison, D., Warnaby, G. and Pal, J. (2010), “Local shopping in the UK: towards a synthesis of business and place”, International Journal of Retail and Distribution Management, Vol. 38 No. 11/12, pp. 846-864.

Birchall, J. (2011), People-Centred Businesses Co-operatives, Mutuals and the Idea of Membership, Palgrave Macmillan, Basingstoke. 
Bitto, E.A., Morton, L.W., Oakland, M.J. and Sand, M. (2003), “Grocery Store Access Patterns in Rural Food Deserts”, Journal for the Study of Food and Society, Vol. 6 No. 2, Winter, pp.35-48.

Blay-Palmer, A. And Donald, B. (2007), "Manufacturing Fear: The Role of Food Processors and Retailers in Constructing Alternative Food Geographies in Toronto, Canada.” In: Maye, D., Holloway, L. and Kneafsey, M. (eds.) Alternative Food Geographies. Representation and Practice, Elsevier, London.

Bovaird, T. (2007), "Beyond Engagement and Participation: User and Community Coproduction of Public Services”, Public Administration Review September/ October, pp. 846-860.

Briscoe, R., McCarthy, O. and Ward, M. (2000), “Ireland's Community Co-operatives”. In The Cooperatives of Ireland, edited by the Centre for Co-operative Studies, Chapter 5, NUI, Cork, Ireland.

Calderwood, E. and Davies, K. (2006), “The impact of community co-operatives on shopping behaviour in rural communities in Scotland”, Review of International Co-operation, Vol. 99 No. 1, pp. 53-62.

Carrigan, M. and Buckley, J. (2008), “'What’s so special about family business?’ An exploratory study of UK and Irish consumer experiences of family businesses”, International Journal of Consumer Studies, Vol. 32, pp. 656-666.

Clarke, I. and Banga, S. (2010), “The economic and social role of small stores: a review of UK evidence”, The International Review of Retail, Distribution and Consumer Research, Vol. 20 No. 2, pp. 187-215.

Cotterill, R. ed. (1982), Consumer Food Cooperatives, The Interstate Printers and Publishers, Danville, IL.

Cox, C. (1994), Storefront Revolution. Food Co-ops and the Counterculture, Rutgers University Press, New Brunswick, NJ.

Danforth, A. (1981), Cooperation Between Cooperatives. A consumer goods cooperative perspective, Art Danforth, Falls Church, VA.

Department for Environment Food and Rural Affairs (DEFRA) (2006) Sustainable Models of Community Retailing, DEFRA, London.

Ekhaugen, K., Grønmo, S. and Kirby, D.A. (1980), "State Support for Small Stores: A Nordic Form of Consumer Policy,” Journal of Consumer Policy, Vol. 4 No. 3, pp. 195-211.

f3 - the local food consultants (2004), Local Products and Village Shops. A report prepared for the Countryside Agency, January.

Fairbairn, B. (1989), Building a dream: The co-operative retailing system in Western Canada, 1928-1988, Western Producer Prairie Books, Saskatoon. 
Fairbairn, B. (2005), Living the Dream. Membership and Marketing in the Co-operative Retailing System, Houghton Boston, Saskatoon.

Fulton, M. and Hammond-Ketilson, L. (1992), “The Role of Co-operatives in Communities: Examples from Saskatchewan”, Journal of Agricultural Cooperation Vol. 7, pp. 15-42.

Gordon, M.J. (2001), "Voyages of discovery: the contribution of the community cooperatives of the Highlands and Islands of Scotland to the development of the social economy”, M.A. Thesis, University of Middlesex, London.

Gray, D., Farrington, J., Shaw, J. Martin, S. and Roberts, D. (2001), “Car dependence in rural Scotland: transport policy, devolution and the impact of the fuel duty escalator”, Journal of Rural Studies, Vol. 17 No. 1, pp. 113-125.

Kirby, D.A. (1981), Aid for Village Shops: A Consideration of the Forms of Aid and Scope for Aid in Britain, Workshop paper URPI S3, Unit for Retail Planning Information, Reading.

Kurimoto, A. (2005), "How Consumer Co-ops Compete by Preserving Community Identity: Case of Tsuruoka Co-op”. Paper presented at The Contribution of Cooperatives to Community Culture, XXI International Co-operatives Research Conference, Cork Ireland, August 12-13, available at: http://www.ucc.ie/acad/foodbus/CCS/ICA/ (accessed 20 February 2009).

Moseley, M.J., Parker, G. and Wragg, A. (2004), "Multi-Service Outlets in Rural England: The Co-Location of Disparate Services”, Planning Practice and Research, Vol. 19 No. 4, pp. 375-391.

Norman, J. (2010) The Big Society. The Anatomy of the New Politics, The University of Buckingham Press, Buckingham.

Paddison, A. and Calderwood, E. (2007), “Rural retailing: a sector in decline?” International Review of Retail, Distribution and Consumer Research, Vol. 35 No. 2, pp.136-55.

Parker, C., Anthony-Winter, T. and Tabernacle, D. (2003), "Learning by stealth: introducing smaller retailers to the benefits of training and education in Barnet", International Review of Retail, Distribution and Consumer Research, Vol. 31 No. 9, pp. 470-476.

Perry, M. and Alcock, J. (2010), "Community Owned Village Shops - A Better Form of Business”, Journal of Co-operative Studies, Vol. 43 No. 2, pp. 37-45.

Shepherd, J. (2005), “Where Do Community Owned Village Shops Work?” Presentation to the Fifth National Rural Social Enterprise Conference, Melton Mowbray, 24/25 November.

Singerman, J. (1982), Starting out right. How to turn your preorder into a retail food cooperative, Blooming Prairie Education/ Outreach Project, Iowa City, IA.

Williams, R.C. (2007), The Cooperative Movement. Globalization from Below, Ashgate, London. 
Winnington-Ingram, P. (2003), “Community Co-operatives: A Revolutionary Model of Rural Community Revitalisation”, Journal of Co-operative Studies, Vol. 36, No. 1, pp. 14-21.

Wrigley, N. (2002), “'Food Deserts’ in British Cities: Policy Context and Research Priorities”, Urban Studies, Vol. 39 No. 11, pp. 2029-2040 
Table 1 : Date at which the sample of CREs began trading

\begin{tabular}{|l|r|r|r|r|r|r|}
\hline & $\begin{array}{c}\text { Estimated CRE } \\
\text { Population, } \\
\text { mid-2009 }\end{array}$ & \multicolumn{4}{|c|}{ Respondents } & \multicolumn{2}{|c|}{$\begin{array}{c}\text { Percentage } \\
\text { response } \\
\text { rate }\end{array}$} \\
\hline & & England & Scotland & Wales & Total & \\
\hline & & & & & & \\
\hline Pre-1980 & 4 & 2 & - & - & $\mathbf{2}$ & $50 \%$ \\
\hline $1980-89$ & 10 & 2 & 3 & - & $\mathbf{5}$ & $50 \%$ \\
\hline $1990-99$ & 38 & 16 & 1 & - & $\mathbf{1 7}$ & $45 \%$ \\
\hline $2000-2004$ & 68 & 33 & 3 & - & 39 & $57 \%$ \\
\hline $2005-2009 *$ & 65 & 31 & - & 3 & 31 & $48 \%$ \\
\hline No date & 12 & & - & & & \\
\hline TOTAL & $\mathbf{1 9 7}$ & $\mathbf{8 4}$ & $\mathbf{7}$ & $\mathbf{3}$ & $\mathbf{9 4}$ & $\mathbf{4 8 \%}$ \\
\hline
\end{tabular}

*Part year 2009 
Table 2 : Reasons for Establishment of the CRE*

\begin{tabular}{|l|r|r|}
\hline Reason & First Choice & \multicolumn{1}{|c|}{$\begin{array}{l}\text { Second } \\
\text { Choice }\end{array}$} \\
\hline & & - \\
\hline Preserve the local shop & 82 & 13 \\
\hline Preserve the local Post Office & 8 & 7 \\
\hline Provide a village amenity & 1 & - \\
\hline Preserve local food supplies & 1 & 3 \\
\hline Help to overcome rural isolation & - & - \\
\hline Other & 2 & $\mathbf{2 3}$ \\
\hline TOTAL & $\mathbf{9 4}$ & \\
\hline
\end{tabular}

* Multiple responses possible 
Table 3 : Community Shop Sales Areas and Average Weekly Turnover

\begin{tabular}{|l|c|c|c|c|c|c|c|}
\hline & \multicolumn{7}{|c|}{ Average weekly turnover (£) } \\
\hline Shop Sales Areas & $\begin{array}{c}\text { Up to } \\
\mathbf{1 0 0 0}\end{array}$ & $\begin{array}{c}\mathbf{1 0 0 1 -} \\
\mathbf{2 5 0 0}\end{array}$ & $\begin{array}{c}\mathbf{2 5 0 1 -} \\
\mathbf{5 0 0 0}\end{array}$ & $\begin{array}{c}\mathbf{5 0 0 1 -} \\
\mathbf{1 0 0 0 0}\end{array}$ & $\begin{array}{c}\mathbf{1 0 0 0 1 -} \\
\mathbf{1 5 0 0 0}\end{array}$ & $\begin{array}{c}\text { Over } \\
\mathbf{1 5 0 0 0}\end{array}$ & Total \\
\hline Less than 250 sq. ft. & 8 & 5 & 2 & 1 & & & $\mathbf{1 6}$ \\
\hline 250 to 499 sq. ft. & 7 & 10 & 6 & & & & $\mathbf{2 3}$ \\
\hline 500 to 999 sq. ft. & 2 & 7 & 9 & & 3 & & $\mathbf{2 1}$ \\
\hline 1,000 to 2,499 sq. ft. & 2 & 2 & 3 & 2 & 1 & & $\mathbf{1 0}$ \\
\hline Greater than 2,500 sq. ft. & & 1 & & & & 1 & $\mathbf{2}$ \\
\hline TOTAL & $\mathbf{1 9}$ & $\mathbf{2 5}$ & $\mathbf{2 0}$ & $\mathbf{3}$ & $\mathbf{4}$ & $\mathbf{1}$ & $\mathbf{7 2}$ \\
\hline
\end{tabular}

* 22 of the respondent stores are missing from this table because they failed to answer one or both questions 
Table 4 : Food products sold by the community retail enterprises

\begin{tabular}{|l|c|c|}
\hline & No. & $\%$ \\
\hline Ambient groceries & 87 & $92.6 \%$ \\
\hline Chilled / frozen foods & 86 & $91.5 \%$ \\
\hline Bakery goods & 85 & $90.4 \%$ \\
\hline Fresh fruit \& vegetables & 80 & $85.1 \%$ \\
\hline Ethical products e.g. FairTrade & 67 & $71.3 \%$ \\
\hline Tobacco products & 67 & $71.3 \%$ \\
\hline Organic foods & 59 & $62.8 \%$ \\
\hline Wines \& spirits & 56 & $59.6 \%$ \\
\hline
\end{tabular}


Table 5 : Non-food products sold by the community retail enterprises

\begin{tabular}{|l|c|c|}
\hline & No. & $\%$ \\
\hline Household goods & 85 & $90.4 \%$ \\
\hline Newspapers \& magazines & 71 & $75.5 \%$ \\
\hline Crafts / souvenirs & 31 & $33.0 \%$ \\
\hline Gardening products & 19 & $20.2 \%$ \\
\hline Stationery & 19 & $20.2 \%$ \\
\hline Fuel (coal, gas etc) & 18 & $19.1 \%$ \\
\hline Electrical goods & 12 & $12.8 \%$ \\
\hline Fuel (petrol/ diesel) & 3 & $3.2 \%$ \\
\hline
\end{tabular}


Table 6 : Services provided by the community retail enterprises

\begin{tabular}{|l|c|c|}
\hline & No. & $\%$ \\
\hline Post Office services & 62 & $66.0 \%$ \\
\hline Sell tickets to local events & 51 & $54.3 \%$ \\
\hline Local information & 37 & $39.4 \%$ \\
\hline Office services (fax, photocopying etc) & 33 & $35.1 \%$ \\
\hline Home delivery service & 27 & $28.7 \%$ \\
\hline Tea room or cafe & 26 & $27.7 \%$ \\
\hline Pay point / Pay zone & 24 & $25.5 \%$ \\
\hline Sell other produce/ second hand goods & 21 & $22.3 \%$ \\
\hline Public internet access & 19 & $20.2 \%$ \\
\hline Tourist information & 17 & $18.1 \%$ \\
\hline Dry cleaning & 15 & $16.0 \%$ \\
\hline ATM & 13 & $13.8 \%$ \\
\hline Pick up prescriptions & 12 & $12.8 \%$ \\
\hline Parcel drop-off & 5 & $5.3 \%$ \\
\hline Video \& DVD Hire & 4 & $4.3 \%$ \\
\hline
\end{tabular}


Table 7: Staff employed by the community retail enterprises

\begin{tabular}{|c|c|c|c|}
\hline & \multicolumn{3}{|c|}{ Number of Community shops with: } \\
\hline $\begin{array}{l}\text { Number of } \\
\text { Staff }\end{array}$ & $\begin{array}{c}\text { Full-Time } \\
\text { (paid) }\end{array}$ & $\begin{array}{c}\text { Part-Time } \\
\text { (paid) }\end{array}$ & Volunteer \\
\hline 1 & 24 & 13 & \multirow{4}{*}{15} \\
\hline 2 & 9 & 11 & \\
\hline 3 to 4 & 1 & 14 & \\
\hline 5 to 6 & - & 10 & \\
\hline 7 to 8 & - & 6 & \multirow{2}{*}{12} \\
\hline 9 to 10 & - & 2 & \\
\hline 11 to 20 & 1 & 4 & 9 \\
\hline 21 to 40 & - & - & 34 \\
\hline 40 or more & - & - & 11 \\
\hline TOTAL & 35 & 60 & 81 \\
\hline $\begin{array}{l}\text { \% of all } \\
\text { respondents }\end{array}$ & $37.2 \%$ & $63.8 \%$ & $86.2 \%$ \\
\hline
\end{tabular}

